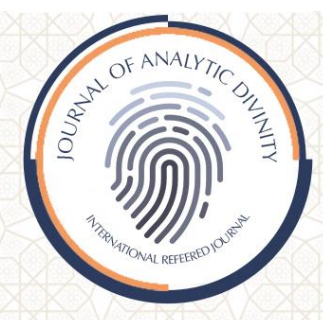

\author{
Journal of Analytic Divinity \\ International Refereed Journal \\ E-ISSN: 2602-3792 \\ Nisan/April 2021/5 (1): ss-pp 205-225
}

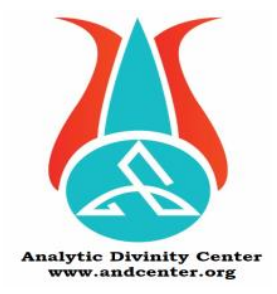

\title{
Kur'an'da Sosyal Kontrol ve Sıla-i Rahim İlişkisi
}

Social Control and Sila-i Rahim (The Bonds of The Kinships)

Relationship in the Qur'an

\section{Muhammed Ahmet Kurum}

Ankara Yıldırım Beyazıt Üniversitesi, İslami İlimler Fakültesi

Ankara Yıldırım Beyazıt University, Faculty of Islamic Studies

\author{
Ankara-Turkey krmahmet13@gmail.com \\ https://orcid.org/0000-0002-3991-629X
}

\section{Makale Bilgisi | Article Information}

Makale Türü / Article Type: Derleme Makale/ Review Article

Geliş Tarihi / Date Received: 13 Ocak/ January 2021

Kabul Tarihi / Date Accepted: 26 Mart/March 2021

Yayın Tarihi / Date Published: 15 Nisan /15 April 2021

Yayin Sezonu / Pub Date Season: İlkbahar-Nisan/ Spring-April

DOI: $10.46595 /$ jad. 859770

Cite as / Atıf: Kurum, Muhammed Ahmet, “Kur'an'da Sosyal Kontrol ve Sila-i Rahim İlişkisi" Journal of Analytic Divinity, 5/1 (April 2021): 205-225.

İntihal: Bu makale, iThenticate yazılımınca taranmıştır. İntihal tespit edilmemiştir. Plagiarism: This article has been scanned by iThenticate. No plagiarism detected. web: http://dergipark.gov.tr/ jad | e-mail to: editorjand@gmail.com

Copyright (C Published by Özcan Güngör, Ankara Yıldırım Beyazıt Üniversitesi, İslami İlimler Fakültesi / Ankara Yıldırım Beyazıt University, Faculty of Islamic Studies, Ankara-Turkey. Bütün hakları saklıdır. / All right reserved. 
Öz

İnsanlar yapılarının bir gereği olarak davranışları noktasında oldukça aktif ve esnek bir hareket alanına sahiptir. Bu alan, olumlu nitelikteki davranışları bünyesinde barındıracağı gibi, suç ve sapma eğilimi gösteren olumsuz davranışları da kapsayabilir. Toplumsal sistem içerisinde meydana gelen söz konusu sapma eğilimleri, soyut ve somut düzlemde formüle edilen sosyal kontrol mekanizmalarıyla önlenmektedir. Sosyal kontrolün olmadığı bir toplum düşünülemez. Her toplumda davranışları yönlendiren normlar mevcuttur. Bu mekanizmalar toplumsal değer yargılarının korunarak veya düzeltmeye tabi tutularak, ayrıntılı ve sistemli olarak işlendiği bir toplum dokusu oluşturur. Aynı zamanda sosyal kontrol, toplumların sosyal yaşantılarının, karşılıklı ilişkilerinin, tavır ve tutumlarının yıkıcı etkilerinin sorgulanmasını ve düzeltilmesini gerektiren bir olgudur. Özellikle çağımızda, geleneksel toplumların aksine insanların tavır ve tutumlarında karşlıklı ilişki dengelerinin sınırlı bir nitelik gösterdiği görülmektedir. Kur'an'ın insan ilişkilerine bakışı ise 21. yüzyılın mevcut anlayışından farklılık göstermektedir. Bu nedenle çalışmada Kur'an'da toplumsal hayatı düzenleyen kontrol mekanizmaları ile sıla-i rahim arasındaki ilişki ortaya konulacaktır. Çalışmanın amacı ise Kur'an'da sosyal bir olgu olarak sıla-i rahimi, sosyal kontrolün boyutları olan olumlu kontrol - olumsuz kontrol başlıkları içerisinde ele almaktır. Çalışmada nitel yönteme bağlı olarak tarihsel dokümantasyon tekniği kullanılmıştır. Çalışmada genel olarak, ilişkilerin devamlılı̆̆ını sağlama noktasında Kur'an'ın sıla-i rahime kazandırmış olduğu işlerlik aracılığıyla edinilen olumlu eğilimlerin, dinin bütünleştirici rolü çerçevesinde toplumsal bir düzen ve istikrar sağladığı sonucuna ulaşılmıştır.

Anahtar Kelimeler: Din Sosyolojisi, Sosyal Kontrol, Sıla-i Rahim, Kur'an, Toplum

\section{Abstract}

People have a highly active and flexible range of motion in terms of their behaviour as a requirement of their structures. This area may include positive behaviours as well as negative behaviours that tend to be criminal and deviating. The aforementioned deviation tendencies that occur in the social system are prevented by social control mechanism formulated in abstract and concrete platforms. A society without social control is unthinkable. These are norms that direct behaviour in every society. These mechanisms create a social fabric in which social value judgements are preserved or refused, in which they are processed in detail and systematically. At the same time, social control is a phenomenon that requires questioning and correcting the destructive effects of societies, social life, mutual relations attitudes and behaviour. Especially, in our age, unlike traditional societies, it is seen that the balance of mutual relations in people's $\mathrm{s}$ attitudes and behaviour has a limited quality. The view of the Quran on human relations differs from the current understanding of the 21st century. Therefore, the study will reveal the relationship between the control mechanisms that regulate social life in the Quran and Sila-i Rahim (The Bonds of The Kinships) 
The aim of the study is to consider S1la-i Rahim (The Bonds of The Kinships) as a social phenomenon in the Quran the unsure positive control -the negative control headings, which are the dimensions of social control. Based on the qualitative method, the historical documentation technique was used in the study. In general, in the study, it was concluded that the positive tendencies acquired through the functionality that see Quran brought S1la-i Rahim (The Bonds of The Kinships) at the point of maintaining the continuity of relations provided a social order and stability within the framework of the integrative role of religion.

Keywords: Sociology of Religion, Social Control, Quran, Society, Sıla-i Rahim (The Bonds of The Kinships)

\section{Giriş}

Sosyoloji tarihinin en kadim sorunlarından bir tanesini toplumsal düzenin nasıl sağlandığı oluşturmaktadır. Dolayısıyla mevcut olan düzeni bozma amacı taşıyan çeşitli öznelerin nasıl dizginlendiği ve hangi şartlar dahilinde kontrol edildiği bu tartışmaların temelinde yatmaktadır. Bu sebepten ötürü toplumsal kontrol mekanizmalarının ne aracılığ1 ile gerçekleştirildiği, özsel olarak ne anlama geldiğinden daha fazla dikkat çekmiştir (Akçakaya, 2019, 412).

Sosyolojinin bir disiplin olarak teşekkül etme sürecinde öne çıkan sosyologlar bu disiplinin temeline toplumu yerleştirmişler ve toplumsal düzenin ve dayanışmanın sağlanmasında öne çıkacak olan toplumsal denetim mekanizmalarının bu doğrultuda ele alınması gerektiğine işaret etmişlerdir. Bu bağlamda sosyal kontrol mekanizmaları makro yapılar çerçevesinde ele alınmış; devletin ve diğer kurumların önemine vurgu yapılmıştır. 20. Yüzyılın başından itibaren, toplumsal sistem içerisindeki bireylerin etkileşimleri üzerine çekilen dikkat, toplum içerisindeki mevcut genel sosyolojik bakışın daha mikro ölçekte ele alındığını göstermektedir. Bu gelişmeyle birlikte bireylerin etkileşimleri üzerindeki öneme vurgu yapılmıştır. “1970'li yıllardan sonra ise sadece makro ve sadece mikro bakış açısıyla sosyal olguların ele alınamayacağı anlayışının yaygınlık kazanmasıyla makro-mikro etkileşimine yapılan vurgu artmıştır. Bu çerçevede de sosyal kontrol anlayışı her iki bakış açısını da içerecek şekilde yeniden düzenlenmiştir." (Bektaş- Bakacak, 2009, 34-35).

Toplum içerisinde bir arada bulunan büyük insan kalabalıklarının eylemlerinin, hal ve hareketlerinin, olası tutumlarının ortaya çıkmadan önce doğru olarak tahmin edilip belli bir temele oturtulmadığı durumlarda, toplumun en küçük yapı birimlerinin bile tam anlamıyla işlemesi mümkün değildir. Doğru temele oturtulmadığı durumlarda mikro boyuttaki yapıların dahi aksayacağı göz önünde bulundurulursa, toplumsal düzeni idame ettirmek için, sistemi oluşturan insanların eylemlerinin, davranışlarının kontrol altında tutulması, böylece toplumsal normlara uygun faaliyetlerde bulunulmasının sağlanması gerekmektedir. Bu durum söz konusu davranış ve tutumların önceden belirlenmesini sağlayacak kontrol mekanizmalarının varlığına ve sorunsuz bir şekilde işlemesine bağlıdır. Toplumsal sistemin içinde yer alan statülerde bulunan insanlar, bu statülerin gerektirdiği rolleri mevcut normlara uygun bir şekilde uyguladıkları takdirde ve yukarıda bahsettiğimiz tahminleri mümkün kıldıkları sürece söz konusu olgu gerçekleşme imkânı

Journal of Analytic Divinity, https://dergipark.org.tr/tr/pub/jad Volume 5/1 
bulacaktır. Ayrıca bu durum toplumu oluşturan kişilerin birbirleriyle bağlantılı olacak şekilde düzenlenmiş bir ilişki ağı kurmalarına da bağlıdır. Bu ağ aksamadan uygulandığ1 takdirde kişiler arasında karşılıklı görevler ve haklar ortaya çıkar (Dönmezer, 1983, 297). $\mathrm{Bu}$ düzen, dünyanın, insan habitatının, insan benliğinin ve bu üçü arasındaki bağlantının düzenidir (Bektaş - Bakacak, 2009, 38). Bu bağlamda Kur'an nazil olduğu toplumun insan varlığını çeşitli açılardan değerlendirmiş, bu değerlendirmelerden birini de akraba gruplarını oluşturan bireyler arasındaki ilişkiler oluşturmuştur. Bu değerlendirme esasında akraba ilişkilerini kapsayan sınırların ne kadar hassas olduğunu vurgulamaktadır.

Elinizdeki çalışmanın konusu, Kur'an'da toplumsal hayatı düzenleyen kontrol mekanizmaları ile sıla-i rahim arasındaki ilişkiyi ortaya koymaktır. Çalışmanın amacı ise Kur'an'da sosyal bir olgu olarak sıla-i rahimi, sosyal kontrolün boyutları olan olumlu kontrol - olumsuz kontrol başlıkları içerisinde ele almaktır.

Çalışma sürecinde gerçekleştirilen literatür taramasında, Eren'in (2008) Kur'an'da birtakım ayetlerde yer alan sıla-i rahim vurgusuna dikkat çektiği, Şahan' ın (2010) akrabalık kavramını Kur'an'da geçtiği şekliyle çeşitli açılardan değerlendirdiği, Demirci'nin (2013) Kur'an ayetleri bağlamında vahiy toplumunda yapılan düzenlemeleri ele aldığı, Berger'in (1999) dinin toplumsal kontrolü sağlamadaki işlevine değindiği görülmüştür. Çalışmada nitel yönteme bağlı olarak tarihsel dokümantasyon tekniği kullanılmıştır. Bu teknik kullanılırken kavramın sosyolojik boyutlarını daha açıklayıcı bir şekilde incelemek için sosyoloji sözlüklerine ve kitaplarına, konuyla ilgili makalelere müracaat edilmiş; Kur'an bağlamında incelemeler yapılırken Kur'an-1 Kerim tefsir ve meallerine başvurulmuş ve çeşitli kitaplardan yararlanılmıştır.

\section{Sosyal Kontrol}

Sosyal kontrol sosyolojide, bireylerin ya da grupların davranışlarını düzenleyen toplumsal süreçleri anlatmak üzere yaygın biçimde kullanılan bir terimdir. Tüm toplumlarda davranışları yönlendiren normlar ve kurallar bulunduğu için (normları olmayan bir toplum tasavvur edilemez), aynı ölçüde hepsinde bu normlara uymayı sağlayacak ve sapkınlıkla başa çıkacak bazı mekanizmalar işlemektedir (Marshall, 1999, 741-742).

Scheerer ve Hess sosyal kontrol kavramını, "sosyal düzenin sağlanması ve buna bağlı olarak ilerlemenin sağlanması amacıyla, tüm istenilmeyen davranışların önlenmesi için geliştirilen sosyal (ve teknik) düzenlemeler, mekanizmalar, inanç sistemleri, olumlu ve olumsuz yaptırımlar" olarak tanımlamaktadır (Scheerer ve Hess 1997)'den aktaran (Bektaş - Bakacak, 2009, 37). Başka bir tanıma göre ise sosyal kontrol, "toplum mensuplarının, diğerlerince beklenen tarz ve şekilde hareket etmelerini ve böylece başkalarının ne tarzda hareket edeceklerini önceden tahmin edebilmemizi sağlayan mekanizmalar, araç ve süreçler" olarak tanımlanmaktadır. Böylece toplum fertlerinin, diğer fertlerin beklentilerine uymaları sosyal kontrol marifeti ile sağlanır (Dönmezer, 1983, 296).

Sosyal kontrol toplum içerisinde düzeni sağlayan, bireyler arasındaki ilişkileri düzenleyen, normlardan sapmayı cezalandırma süreci ile, normlara uygun davranışları ise ödüllendirme ile pekiştiren bir süreçtir (İçlï - Burcu, 1993, 44). Sosyal kontrolün olmadığ1

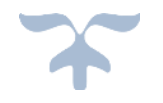


bir toplumda düzenden söz etmek mümkün değildir. Düzenin olmadığı bir toplumda ise düzensizlik, kaos, kuralsızlık yaşanırken, örgütlenmenin de olmamasıyla bireylerin birbirini yok sayarak uzlaşma ortamını reddetmeleri gerçekleşir. Dolayısıyla düzenin sağlanması ancak sosyal kontrolle mümkün olup hem birey hem de toplum varlıklarını bu kontrolle sürdürebilirler (Oktik, 2013, 1/300).

Sosyal kontrol mekanizmaları bireylere zorla kabul ettirilen bir şey değildir. İnsanlar toplumsal hayat içerisinde öyle çok sosyalleşirler $\mathrm{ki}$, sürekli tekrarlanan bu sosyalleşmelerin sonucu olarak normları ihlal ettikleri zaman mutsuz bir ruh haline bürünürler. Normların ihlali sonucu çeşitli baskılar, itibar kaybı, güven eksikliği gibi kaybedilmesi olası olan değerler, insanların davranışlarını şekillendirmekte, ihlallerin önüne geçmektedir (Okumuş, 2014, 445).

Suçun Nedenleri (1969) adlı kitabında Hirschi insanları yasalara uygun hareket etmeye sevk eden ve topluma bağlayan dört tür bağ olduğunu ileri sürer. Bunlar bağlanma, adama, içerilme ve inançtır. Bu dört unsur yeterince güçlü olduğu takdirde bireylerin kuralları yok sayma özgürlüklerini ortadan kaldırarak toplumsal kontrolün sağlanmasına yardımcı olacaktır. Aksi takdirde bu bağların zayıfladığı durumlarda sapma ve suç eğilimleri baş gösterecektir (Giddens, 2006, 805). Sosyal kontrol kavramı toplumsal bozuklukları düzenleme işlevini görse de temelde toplumsal sistemin nasıl işlemesi gerektiğini de baz alan bir yönetim pratiğidir. Sosyal kontrol mekanizmaları sistemin işlemesini engelleyen davranışların kurumlar aracılığıyla önlenmesi ve tekrarının önüne geçmeyi sağlayan yönetim aracı olarak tanımlanabilir (Şahin, 2019, 70).

Toplumsal düzeni sağlaması bakımından sosyal kontrol, mevcut normların dişına çıkma olarak tanımlayabileceğimiz sapma davranışlarının düzeni bozacak şekilde ortaya çıkmasıyla kendini hissettirir (İçlï - Burcu, 1993, 44). Cohen sosyal kontrolü; "sapmış davranışları engellemeye yönelik olarak geliştirilmiş tüm tutum ve davranışları içeren girişimler" olarak tanımlamaktadır (Bektaş - Bakacak, 2009, 35). Dolayısıyla sosyal kontrol ve sapma kavramları birbirleriyle içiçe geçmiş kavramlardır. Toplumsal yapının üstlendiği en temel işlev, sapma davranışlarını gerçekleştiren bireylerin kontrol altına alınması ve toplumsal dayanışmanın gerçekleştirildiği bir yapıyı garanti etmesidir. Sapma davranışlarının imkanını ortadan kaldırmak için kontrol mekanizmalarını devreye sokmaktadır. Bu doğrultuda hem makro yapısal örgütlenmeler hem de mikro ölçekli sistemler bireyleri kontrol altında tutmakta, dayanışmanın ve düzenin sağlandığı bir topluma aidiyetlerinin sorunsuz olması noktasında uyarılarda bulunmaktadır. Normların dışına çıkarak telkinleri yok sayan bireylere çeşitli cezalar uygulamakta, bir sonraki sapma davranışının ne olabileceği ve nasıl önleneceği üzerine çalışmalar yapmaktadır (Akçakaya, 2019, 435). Nitekim bireyler sosyalleşme süreçleri ile sınırlı olmadıkları takdirde geniş bir faaliyet yelpazesinde yer alabilecek aktif ve esnek organizmalardır (Burke, 2009, 246).

Sosyal kontrol, bireylerin davranışlarının toplumsal değerlere ve toplumsal yapıya uygun olmasını sağlar. Değerlerin ve normların birbirleri üzerindeki tamamlayıcı etkileri, Durkheim'in toplumsal düzenin devamını sağlaması ve varlığını sürdürmesi için gerekli olan güç olarak tanımladığı kolektif bilincin ortaya çıkmasını sağlamaktadır. Hem tek tek kurumlar bazında hem de genel olarak toplumsal yapının değerlerini koruyan bir mekanizma olarak karşımıza çıkan sosyal kontrol gücünü, söz konusu bu bilinçten almaktadır (Yazıc1, 2014, 219).

Journal of Analytic Divinity, https://dergipark.org.tr/tr/pub/jad Volume 5/1 
Toplumsal kontrol mekanizması sosyalizasyon sürecinin bir uzantısı olarak karşımıza çıkmaktadır. Sosyalizasyon ise bireylerin toplumda kabul görmüş olan davranışları öğrenmesi ve uygulamasıdır. Bu süreçte kişinin o toplumda büyümüş olması veya başka bir toplumdan gelmiş olması arasında fark yoktur. Nitekim bireylerin sağlamış olduğu bu uyum toplumsal yaşamı ve dayanışmayı mümkün kılar (Fichter, 2016, 207). İnsanların sürekli iletişim halinde bulundukları toplumlarda sosyal kontrol mekanizmalarının işlevini tam anlamıyla yerine getirebilmesi için, toplumu oluşturan kişiler sosyalizasyon süreciyle birebir bağlantılı olan kişilik ve karaktere sahip olmalıdırlar $\mathrm{ki}$, toplumsal normların gerektirdiği şekilde hareket etmeye, eylemde bulunmaya mecbur oldukları bilincini kazanarak, bu bilinç doğrultusunda davranmayı istesinler. Bu süreç ise kişilerin sosyalleştirilme aşamalarının başarısıyla ilişkilidir. Nitekim başarı ile uygulanan bir sosyalizasyon süreci, kişilerin kendileri için uygulanması zorunlu olan normları arzu ederek gerçekleştirmesini sağlayacaktır (Dönmezer, 1983). Aristo'nun “antropos zoon politikon." (İnsan toplumsal bir canlıdır) cümlesiyle ifade etmeye çalıştığı gerçekliği, İbn Haldun çok daha veciz ve doyurucu bir cümleyle ortaya koymaktadır: el-ictimâ'u'linsâniyyu darûriyyun." (İnsan için toplum zorunludur). İnsan doğası gereği sosyal bir varlıktır. Dolayısıyla sosyalleşmesi de zorunludur. Bu zorunluluk durumu, bireyin toplumdaki varlığını sorunsuz bir şekilde sürdürmesi için önem arz eder (Okumuş, 2014, 431).

\section{Sosyal Kontrol Vasitaları}

Toplumlar resmi olarak kayda alınan normlara ve yaptırımlara ek olarak, sonraki nesillere miras olarak veya çeşitli yollarla aktardıkları informal normlar sayesinde kendi içerisinde barındırmış olduğu bireyleri ve grupları kontrol ederek toplumsal devamlılığı sağlamış olur (Tekïn, 2006, 219). Temel olarak toplumsal kontrolü sağlayan unsurlardan en belirgin olanı yasalar ile teminat altına alınmış olan kurallardır. Fakat buna ek olarak bireyler kurallara uymayı eksiksiz ve sürekli olarak sağlamak için resmi kurallar dışında toplumun içselleştirdiği değer yargılarına da ihtiyaç duyarlar. Söz konusu bu kurallar toplumun inanç biçimleri, adet, örf gelenek ve görenekler, ahlak gibi çeşitli unsurlarla açıklanabilir. Geleneksel toplumlarda bahsettiğimiz bu yaşam biçimini görmek daha olasıdır. Bu toplumların belli bir kalıba oturmasında öne çıkan güç genel olarak din, cinsiyet, davranış biçimleri, etnisite gibi çeşitli unsurların oluşturduğu, grup içi yaklaşımında baskın karaktere sahip olan kültür etrafında şekillenen toplumsal ilişkiler ağıdır. Dolayısıyla mezkûr kültürel çevre, bireylerin davranış şekilleri üzerinde belirgin bir etkiye sahip olarak, nasıl davranılması gerektiği üzerinde, toplumda kalıplaşmış rolleri sunar. Bu durum içerisinde, kişiler tarafından kabul ve onay gören kuralların ihlali gündeme geldiğinde, kültürel baskı toplumsal kontrolün sağlanmasında öne çıkmaktadır (Nar, 2013, 274). Bütün toplumlarda, içsel yapıları dahilinde kendilerine özgü ahlak, örf, din gibi toplumsal ve kültürel yaşamı şekillendiren ve belli bir kalıp içerisinde yerleştiren yapilanmalar bulunur. Bu yapilanmalar esas olarak geleneksel toplumlarda etkin olan yaşam biçiminin uygulandığı informal özellikli yapılanmalarda daha da öne çıkmaktadır. Geleneksel kontrol mekanizmaları çeşitli faktörlere göre değişiklik gösterebilir. Değerler, inançlar, örgütlenmeler, coğrafi faktörlere ve bunlar gibi birçok etken bu değişikliklerin 
sebebidir. Coğrafi şartların hayat şartlarını zorlaştırdığı toplumlarda, insani ihtiyaçların sağlanması için informal kontrol mekanizmaları büyük önem taşımaktadır. Ayrıca ataerkil toplumlarda da aynı durum söz konusudur (Nar, 2013, 277).

Modern toplumlarda ise durum daha farklıdır. Fransız devrimi ve sanayileşme süreci ile öne çıan modernleşme ile birlikte mevcut sistemlerin prestijinin büyük oranda değer kaybetmesiyle ortaya çıkan düzen sorunu çeşitli tartışmaların etrafında şekillenmekle beraber, sosyal/toplumsal kontrol kavramıyla da birebir ilişkilidir (Bektaş - Bakacak, 2009, 38). Bu sürecin en temel özelliği ise, toplumsal sistemi önceden tasarlanmış bir düzen modeline göre biçimlendirip yönetmek için gerekli kaynaklara ve iradeye sahip yeni bir tür devlet iktidarının ortaya çıkmasıdır (Bauman, 1996, 8). Bauman'a göre düzen kavramındaki tarihsel değişim modern çağın başlamasıyla gerçekleşmiştir. Dolayısıyla moderniteyi, Bauman' ın ifade ettiği gibi “tevarüs edilen geleneksel düzenin bozulması ve varlığın daimî bir yeniden başlama anlamına geldiği zaman ya da yaşam biçimi" olarak tanımlayabiliriz (Bauman, 2000, 21). Modernite ile birlikte yeniden anlam kazanan sosyal kontrol söylemi, düzeni bozma potansiyelini içeren her türlü kirden arınmayı içerir. Toplumda egemen olan iktidar, modern çağla birlikte hemen hemen her alanda gerçekleşen değişimlerin getirmiş olduğu kargaşa durumunu en aza indirmek, bu kargaşa ortamının getirmiş olduğu tehditleri bertaraf etmek için güven içerisinde bir düzen sağlamakla yükümlüdür (Bauman, $2000,22)$.

Bu düzeni sağlamada Marks'a göre devletin sosyal baskı araçları öne çıkmaktadır. Bu aygitlar, hükümet, yönetim, ordu, polis, mahkemeler, hapishaneler gibi araçlar olmakla birlikte, Dini DİA1 , Öğretimsel DİA, Aile DİA'sı, Hukuki DİA, Siyasal DİA, Sendikal DİA, Haberleşme DİA'sı ve Kültürel DİA da kontrolün sağlanmasına hizmet ederler (Bektaş Bakacak, 2009, 39). Foucault iktidarın kontrol mekanizmalarını sağlamasında sahip olduğu üç güç boyutundan bahsetmektedir. Bunlardan ilki insanların zamanlarını belirli kurallar dahilinde düzenleyen ve adeta makine dişlisine çeviren "disiplindir". İkinci olarak insan aktivitelerinin yönlendirilmesi anlamına gelen ve evrensel standartlar dahilinde insan hayatını normalize eden "terbiye etme" kavramı karşımıza çıkmaktadır. Son olarak "gözetim" karşımıza çıkar. Gözetim insan hayatının sürekli olarak incelenmesidir. Her birey her an kontrol altında tutulmalıdır. Kontrol sağlanmadığı takdirde modern toplumun kontrol mekanizmalarının sorunsuz işlemesi mümkün değildir (Demir, 2009, 5). Gözetimle birlikte toplumun bütün üyeleri sıkı bir denetime tabi tutulmakta ve istenilen durumlar sağlanmaktadır. Kontrol altında tutulan bireyler arasındaki farklılıklar gözetimin sağlamış olduğu denetim imkânı ile, bireylerin aynı rutin davranışları uygulaması sağlanarak ortadan kaldırılmakta ve toplumsal düzen korunmaktadır (Bektaş - Bakacak, 2009, 42).

\section{Sosyal Kontrol Yaklaşımları}

Literatürde farklı sosyal kontrol yaklaşımları söz konusudur. Sosyal kontrol kavramı formel ve informel olmak üzere iki kısma ayrılabilir. Birbirinden bağımsız olmayan bu iki kısım toplumda var olan sapma davranışlarını düzenlemeleri itibariyle birbirleri ile iç içe geçmiştir. Söz konusu kavramın her iki boyutu da toplumda düzensizliklerin artması, kargaşanın toplumu ele geçirmesi, toplumsal normların işlevini yitirmesi gibi durumlarda

\footnotetext{
${ }^{1}$ DİA: Devletin İdeolojik Aygıtları.
} 
kendini gösterir. Ortaya çıkan sapma davranışlarına toplumun gösterdiği tepkinin boyutuna göre ise sosyal kontrol kavramı yukarıda bahsettiğimiz iki kısma ayrılmıştır (Burcu, 1992, 73). Formal kontrol genel olarak iktidarın yasalar, düzenlemeler şeklinde uygulamış olduğu kontrol türü iken, informal kontrol ise toplumun sahip olduğu değerlerle, örf ve adetlerle şekillenen bir kontrol mekanizmasıdır (Vural, 2011, 8). Sosyal kontrol üzerinde yapılan çalışmalara önemli katkılar sağlayan Stanley Cohen kontrol mekanizmalarını politik-antropolojik ve suç ve sapma boyutlarıyla sınıflandırmıştır. Politik boyut, sosyal kontrolün düzen, otorite ve yasallaştırılmasıyla ilişkilidir. Düzenin sağlanması ancak yasalarla ve otoritenin en iyi şekilde kullanılmasıyla mümkündür. Toplumda meydana gelen düzeni bozmaya yönelik eğilimler bu yasalarla denetim altına alınarak tekrarlanmasının önüne geçileceği fikri hâkimdir. İkinci boyut olan antropolojik boyuta göre sosyal kontrol, toplumda yer alan değerlerin ve normların içselleştirilmesi üzerine temellendirilir. Üçüncü boyut olan suç ve sapma boyutu ise suçu önlemeye yönelik geliştirilen pratikleri kapsamaktadır (Bektaş - Bakacak, 2009, 36). Nye ise dört tür sosyal kontrol tespit etmiştir: 1) Geleneksel normlarla uyumu sağlamak için ödül ve cezaya dayalı doğrudan kontrol 2) Temel olarak geleneksel anlamda diğerlerine bağlı harekete dayalı dolaylı kontrol 3) Kişilik, öz-denetim ve vicdana dayalı içselleştirilmiş kontrol 4) Kısıtlı tercih ve alternatiflerle uyum sağlayarak fırsatlar üzerinde sağlanan kontrol (Altuntop, 2012 , 2). Fichter ise sosyal kontrolün uygulanması bağlaminda üç genel sinıflandırma üzerinde durmaktadır: Olumlu - olumsuz kontrol, resmi - gayri resmi kontrol ve grup kontrolü - kurumsal kontrol (Fichter, 2016, 208). Konunun bağlamindan dolayı bizi daha çok olumlu-olumsuz kontrol yaklaşımları ilgilendirmektedir.

Ödüllendirme, eğitme, ikna çabaları gibi çeşitli olumlu söylemler, bireylerin toplumsal normların dışına çıkmasını önler. Toplum tarafından geçerliliği kabul edilmiş davranışları uygulama noktasında bireyi teşvik eder. Bu olumlu söylemlerin tersi olan olumsuz söylemler ise zorlama, tehdit, cezalandırma gibi kavramlarla tanımlanabilir. Bu olumsuz söylemler sapkın davranışların önlenmesi için kullanılmaktadır. Söz konusu her iki kontrol biçimide toplumsal denetimi gerçekleştirmede birlikte hareket eder. İnsan yapısı itibariyle karmaşık bir güdülenmeye sahiptir. Nitekim birey ödül almak için veya ceza almaktan korktuğu için toplumda kabul görmüş davranışların gerektirdiği gibi davranır (Fichter, 2016, 209).

Toplum içerisinde uyumluluğu sağlam temeller üzerine dayandırmak için resmi olarak belirlenmiş birtakım kurallar vardır. Bu kurallar iktidar tarafından tasarlanmış yasalar olarak karşımıza çıkar. Resmi olarak isimlendirilme sebepleri ise iktidarın otoritesini kabul eden herkes tarafından kabul edilmiş olmasıdır. Gayri resmi kontrol ise, resmi kontrol kadar etkili olmakla birlikte resmi müeyyidelere bağlanmamış davranışları isimlendirmek için kullanılır. Kişiler çeşitli davranışlarının arkasından toplumun diğer üyelerinin onayını gözeten bir anlayışa sahip oldukları için, resmi olarak belirlenmemiş davranışlarının kabul edilebilir olduğunu bu kontrol biçimi ile anlarlar (Fichter, 2016, 209).

Grup kontrolü esas olarak kontrol eden ve kontrol edilen unsurların birbirleri üzerinde bilinç, gönüllük veya kasıtlı hareket yoluyla uyumun kurulmasına dayanmaktadır. Kurumsal kontrol ise bireyin içinde bulunduğu toplumun kültürel değerlerini bilinçsiz olarak kabul etmesidir. Birey sosyalizasyon sürecinin ve uzun 
deneyimlerin sonucu olarak alışmış olduğu davranış örüntülerine irdelemeden uymaya devam eder (Fichter, 2016, 209-210).

\section{Din ve Toplumsal Kontrol}

Din özü itibariyle toplum içerisinde önemli bir sosyal enstrüman olarak karşımıza çıkmaktadır. İnsan ise çeşitli şekillerle sosyal hayata sürekli olarak aktif katılım sağlayan sosyal bir varlıktır. Dolayısıyla içiçe geçmiş bu iki kavram bireye dinin de sosyalleşme sürecinin içinde yer aldığı bir deneyim imkânı sunar. Sonuç olarak dinin etkili olduğu bir toplumsal yapıda, sosyalleşmenin dinden bağımsız gerçekleşmesi söz konusu olamaz. Dinin sosyalleşme sürecinde öne çıan bir diğer yönü ise sosyal kontroldür. Sosyalleşmenin din ile olan yakın ilişkisinin sonucu olarak bireylerin norm ve değerlerin çizgisini aşmalarını önleme görevi görmesiyle, etkin bir kontrol mekanizması olarak karşımıza çıkar. Meşrulaştırma ve muhafazakarlık yönleriyle din, toplumdaki aktörlerin sosyal düzenlemelerin sınırlarını aşmalarını önler (Okumuş, 2014, 442-445).

Dinin toplumla ilgili önemli fonksiyonlarından biri "toplumu düzenleyici normlar sistemi" olmasıdır. Din müminlere toplumsal hayat içerisinde nasıl hareketler sergilemeleri gerektiğini temel alan düzen odaklı bir sistem sunmaktadır. Bu bağlamda dinin normlar eşliğinde toplumu düzenleyici özelliği belirgin olarak İslam toplumlarında karşımıza çıkar. Dinin dünya karşısındaki tavrı esas olarak müminlerin zihniyet yapılarını yeni bir form temelinde şekillendirmeye dayanır (Güngör, 2004, 34).

Toplumda kontrol mekanizmalarının temsilcilerine itaatin dini bir emir ve itaatsizliğin ise günah olarak kabul görmesi dine meşrulaştırma işlevini vermek demektir. İktidarın meşru bir hal alması toplumsal düzenlemelerin söz konusu olduğu zamanlarda bireylerden çeşitli konularda büyük fedakarlıklar yapmaları istenildiğinde büyük önem kazanır. Toplumlar için büyük bir önem arz eden evlilik, helal yollarla kazanç elde etme gibi çeşitli konular dinin meşrulaştırma yönüyle birlikte toplumsal kontrollere büyük bir güç kazandırmış olur (Berger, 1999, 85).

Sosyal kontrol bireyi sadece dişsal olarak etkilemez. Bireyin içselleştirmesini sağlayarak vicdani duygularını harekete geçirir. "Gerçekten de kurallar kişinin vicdanında köklü bir yer edinmedikçe, dıştan gelen kontrolün etkili olması pek düşünülemez. Bu süreçte dinin nasıl etkide bulunduğunu kolayca görebiliriz. Dinin, toplumsal hayatta hoş karşılanmayan işlerden uzak tutacak şekilde insan bilincini şekillendirebilmesi onun en belirgin, herkesçe arzu edilen ve bilinen en "açık" etkilerinden veya işlevlerinden birisidir. Dinsel olarak şekillenmiş bilincin belirli özellikleri, elbette, zaman ve mekân açısından görecelidir. Orta çağda yaşamış biri, bir büyücünün yakılmamasını günah olarak kabul ederken, biz bugün yakılmasını günah kabul ediyoruz. Gelenekçi bir Güneyli beyaz, siyahlarla beyazların birbirine karışmasını, ihtimal olarak dahi, günah addederken; aynı dine mensup Kuzeyli, siyah ve beyaz ırkı birbirinden ayıran geleneksel araç ve amaçların uygulanmasını günah telakki eder." (Berger, 1999, 85-86). Sosyal kontrol bireyleri sadece dışarıdan yüzeysel olarak etkileyen bir kontrol mekanizması değildir. Bireyin vicdanen kabul edeceği ve içselleştireceği bir tarzda kendini gösterir.

Din normalde kabul edilmesi güç olan şeyleri meşrulaştırma işlevi görmesiyle de önemlidir. Ölmek ve öldürmek büyük oranda şiddet içeren kavramlardır. Fakat bir askerin

Journal of Analytic Divinity, https://dergipark.org.tr/tr/pub/jad Volume 5/1 
vatan, din gibi çeşitli etkenlerin zarar görmesini engellemek için gözü kapalı bir şekilde savaşması veya dinsel bir ritüelin gerçekleşmesi için ölmeyi kabul eden bir insanın bu davranışı dinin meşrulaştırma işlevinin uzantılarıdır. Her iki durumda da olayların şiddet içeren yönlerinin görmezden gelinerek dinsel bir şekilde sembolize edilmesi ve mutlak şekilde doğru olarak kabul edilmesi söz konusudur (Berger, 1999, 85).

\section{Kur'an ve Sosyal Kontrol}

Allah insanları gerek sahip oldukları kabiliyet gerekse fiziksel özellikleri ve ruhsal yapıları itibariyle çeşitli noktalarda birbirinden farklı yaratmıştır. Doğal olarak bu durum, hayatın her alanında birbirlerine ihtiyaç duyan insanları bir arada yaşamaya sevk etmiştir (Güngör, 2004, 37). Sorunsuz olarak işleyen bir toplumsal düzen hayatın bütün alanlarını kapsayan, paylaşılan anlayışlar ve değerler yoluyla gerçekleşir. Söz konusu bu değerler artık tartışmalı bir hale geldiyse toplumda anomi yaşanması kaçınılmazdır (Şentürk, 2009, 71). İslam dini, toplumu yeni bir düzenlemenin sonucu olan hukuk kuralları çerçevesinde Allah'ın iradesini esas alarak düzenlemek üzere gönderilmiş, aynı zamanda toplumsal hayatın yeniden düzenlenmesi ve ilahi kaideler etrafında değişimin sağlanması sürecinde sıradan bir kurum veya üstyapı değil, değişimin temel belirleyici unsuru olarak karşımıza çıkmaktadır. Bu noktada vahyi, tarihe yaradan tarafından gerçekleştirilen bir müdahale olarak ele almak gerekir. Bu müdahalenin en son ve en belirgin tecellisi Kur'an' dır (Şentürk, 2014, 25). Dolayısıyla "Kur'ân, doktriner öğretisine ilaveten, Müslümanların toplum hayatına ilişkin ibadetle ilgili veya hukûkî-sosyal hükümleri de ihtivâ eder." (Watt, 2000, 184)' den aktaran (Karazeybek, 2008, 40). Bu bağlamda Kur'an'in toplumda kontrolü sağlamak için ıslah ettiği birçok kurum bulunmaktadır. Sosyolojik olarak ele alındığ 1 zaman, bu kurumlar insanların uzun süreçler sonunda oluşturmuş oldukları kültürlerinin ve yaşam tarzlarının önemli birer unsurudur. Bu unsurlar önemli toplumsal ihtiyaçları karşılamak üzere doğmuş değer yüklü, normatif yapılardır (Demirci, 2013, 26). Kur'an bu yapıları düzenleyerek, bu kavramlar etrafında şekillenebilecek olası sapma eğilimlerinin önüne geçmiştir.

\section{Sosyal Kontrol Yaklaşımları Bağlamında Sıla-i Rahim Vurgusu İçeren Ayetlerin Ele Alınması}

\section{Etimolojik olarak Sıla-i Rahim}

Sözlükte "bağ, ilişki" anlamına gelen sıla ile "ana rahmi" ve mecazen "insanlar arasındaki soy birliği, akrabalık bağı" mânasındaki rahm/rahim (çoğulu erhâm) kelimelerinden oluşan sıla-i rahim istılahta ise "kan bağı ve evlenme yoluyla oluşan akrabalık bağlarını yaşatma, akrabalarla ilişkiyi sürdürme, haklarını gözetme, onlara ilgi gösterme, iyilik ve yardımda bulunma, ziyaret etme" şeklinde açıllanmaktadır. Bu tür akrabalık görevlerini ihmal etme veya akrabalara kötü davranma durumu kat'-1 rahim tabiriyle ifade edilmektedir (İbnu'1 Esir, T.y, 191-192). Ayet ve hadislerde ele alınan sıla-i rahim kavramının kimleri kapsadığına dair farklı görüşler mevcuttur. Kimi alimlere göre kendisiyle evlenilmesi haram olanlar, kimilerine göre kendilerine varis olanlar, kimi alimlere göre ise mahrem olsun olmasın, insanın bütün yakınları olarak tanımlanmıştır 
(Eren, 2008, 369). Mekke döneminde nazil olan ayetler ele alındığında Allah'ın ilk olarak kendisine imanın üzerinde durduğu, devamında ise anne babaya hürmetin ardından akrabalık ilişkilerine vurgu yaptığı dikkat çekmektedir (Filinte, 2018, 302).

\section{Olumlu Bir Kontrol Mekanizması Olarak Sıla-i Rahim}

Toplumlar ve gruplar, içinde yaşayan fertleri belirli şeyleri yapmaya, birtakım şeylerden de sakındırmaya çalışırlar. Olumlu kontroller sadece soyut bir düzlem içerisinde gerçekleştirilebilir. Soyut düzlemde gerçekleştiriliyor olması, gerçekte somut düzen içerisinde toplumsal kontrol hedefinin sağlanması hedefine doğru hareket edildiği gerçeğini değiştirmez (Fichter, 2016, 209). Allah, akrabalarla ilişkilerin sağlam temeller üzerine kurulmasını tavsiye etmiş, konuyla ilgili akıl sahiplerinin niteliklerinin sıralandığı bir ayette inanan kimseler, Allah'ın korunmasını emrettiği bağı koruyan, Rablerine saygıda kusur etmeyen ve hesabın kötü sonuç vermesinden korkan kimseler olarak nitelendirilmiştir (Rad 13/21). Ayette Allah'ın gözetilmesini emrettiği şeyi gözettikleri, yani insanlık, akrabalık, din kardeşliği ve benzeri ilişkilerden doğan haklara riayet ettikleri, kulluk görevlerinden kusur etmemeye çalıştıkları ele alınıyor. Dünya hayatının güzel sonu olan cennet, Allah'ın rızasını kazanmak için çabalayan bu kimselere mükafat olarak sunulacaktır. İlgili surenin devamı olan (Rad 13/21-23) ayetlerde kulluk görevlerine riayet eden kimselerin adn cennetlerine (ilgili ayetler Tevbe 9/72; Nahl 16/31; Meryem 19/61; Fâtır 35/33) gireceği vaad edilmektedir. Bireyler arzu ve duygularına göre mutlu olabilmek için cennette dahi yakınlarıyla birlikte olmak ister. Bu istek ve arzular ilgili pasajın (Rad 13/21-23) 23. ayetinde olumlu bir şekilde karşılanırken, aynı zamanda iman, ahlak bütünlüğünün sağlanması şartına bağlanmaktadır. Aksi halde cennetlik kimselerin yakını olmak kişiye oraya girme hakkını vermeyecektir (Karaman vd., 2007, 3/286). Sosyal adaletin sağlanması ve İslam'ın insanlara aşıladığı merhamet, şefkat, karşılık beklemeden yardım gibi çeşitli erdemlerin bildirildiği bir ayette (Nisa 4/8), söz konusu erdemlerin uygulanmasının akrabalar arasında ve insan ilişkilerinde soğukluk, kıskançlık, dışlanmışlık gibi olumsuz duyguların girmesini önleyeceği bildirilmektedir (Karaman vd., 2006, 2/21). Nitekim "İslam dini Allah tarafından belirlenmiş ahlaki sınırlar içinde çeşitli etkinliklerini uzlaştıran, dengeli insanlardan meydana gelmiş toplumsal bir çevre oluşturmayı amaçlamaktadır." (Nakvi, 1985, 54).

Ödüllendirme, eğitme, ikna çabaları gibi çeşitli olumlu söylemlerin, toplumsal normların başarılı bir şekilde sağlanması için önem arz ettiğine daha önce değinmiştik. Bireyler cezai yaptırımlardan sakınmak için düzeni bozma potansiyeline sahip sapma eğilimlerinden mümkün olduğunca uzak durmaya çalışırlar. Bu durum ise bireylerde doğrudan ödül üzerine bir güdülenme oluşturarak ödülü kapsayan davranışlara yöneltir. $\mathrm{Bu}$ bağlamda olumlu kontrol mekanizmalarının işletilmesi toplumsal organizasyonu geliştirici eylemleri kapsar.

Mezkûr ayetlerde ( $\operatorname{Rad} 13 / 21)$ dünya hayatının olumlu sonu olan cennetlerin Allah'ın gözetilmesini emrettiği davranışları yerine getiren kimselere ödül olarak sunulacağı bildirilmektedir. Zaaf ve eğilimlerin sunmuş olduğu geçici hoşnutlukların bir kenara bırakılarak ayetin ihtiva ettiği konuların pratikte uygulanması kişiyi mükafatına ulaştıracaktır. Davranış düzleminde Kur'an'ın bildirdiği çeşitli erdemlerin uygulanması, akrabalık ilişkileri ve toplumsal ilişkilerde toplumsal organizasyonu zedeleyici ve

Journal of Analytic Divinity, https://dergipark.org.tr/tr/pub/jad Volume 5/1 
engelleyici olumsuzlukları önleyerek tutarlılık ve yapıcılık içerisinde, maneviyat yoksunluğundan uzak bir toplum düzenini teminat altına alacaktır.

“Allah'ın yerine getirilmesini emrettiği şeyleri yerine getirirler." (Rad 13/21) ayetinde hak ve hukuka riayet etmenin önemi üzerinde durulmakta, peygamberlerin ve onların mirasçıları olan alimlerin, hısım akrabanın, komşunun ve bütün müminlerin, zimmet sahibi gayrimüslimlerin ve hatta karıncalara kadar hukuka riayet etmenin önemi üzerinde durulmaktadır (Yazır, 1992, 5/141). Bu noktada Türk kültüründe karıncayı bile incitmemek deyim halini almıştır (Yılmaz, 2019, 321). Bütün yaratılmışların haklarına sayg1 göstermek bu ayetin ihtiva ettiği anlamlar içerisinde yer almaktadır (Yazır, 1992, 5/141). Allah'ın kullarından yapmasını istediği ahlaki emirler hayır, iyilik, husn, adalet, salih amel gibi hem genel olarak toplumun hem de bireysel olarak insanların mutluluğunu ve faydasını sağlayan emirlerdir. Aynı şekilde Allah'ın yasakladığı davranışlar ise fısk, fitne, kötülük, zulüm gibi insanlığın emniyetini ve mutluluğunu ortadan kaldıran sıkıntı verici davranışlardır (Güler, 1998, 33).

Yüce Allah'ın sürdürülmesini emrettiği akrabalık ilişkileri her çağda Müslümanların sahip olmak durumunda oldukları nitelik ve karakteristik özellikler arasında zikredilmektedir (Derveze, 2014, 4/408-409). İnsanların yakın akrabalarına karşı göstermiş olduğu sevgi, fıtrata dayanan bir özelliktir. Bu bağlamda (Nur 24/22) kişinin öfkeli anlarında bile akrabalarından merhameti esirgememesi emredilmektedir. Bu durum sıla-i rahime teşvik ve yöneltmede ve akrabalara karşı yumuşaklık ve nezaketle muamele etmede üst bir mertebeyi ihtiva etmektedir (İbn Kesir, 1991, 11/5811). Bu ayet Hz. Ebû Bekir ile Mistah b. Üsase arasındaki olay hakkında nazil olmuştur. Hz. Aişe' den gelen bir rivayete göre ifk hadisesi bağlamında kendisini temize çıaran (Nur 24/11-22) ayetler nazil olduktan sonra Hz. Ebubekir Mistah b. Usase' ye bir daha yardım etmeme kararı almıştı. ${ }^{2}$ Bunun nedeni de Mistah 'ın ne yakınlığa ne de Ebubekir' in kendisine ve ailesine yapmış olduğu yardımlara itibar etmemiş olmasaydı. Bunun üzerine nazil olan bu ayeti (Nur 24/22) duyan Hz. Ebubekir "Vallahi biz Allah'ın bizi bağışlamasını arzu ederiz." dedi. Devaminda ise Mistah'a öncekinden daha cömert olan yardımlarına devam etmeye başladı. Diğer bazı sahabeler de ifk olayı bağlamında iftirada rol oynayanlara karşı yemin etmeme kararı almışlardı. Onlarda yeminlerini geri aldılar (Mevdudi, 1991, 3/510-511). Nitekim bu hususta Hz. Peygamber "......Sıla-i rahmi kesmek üzere yemin edenin de edilmiş bir yemini yoktur" buyurmuştur (Sicistani, 1989, 8/367).

\footnotetext{
${ }^{2}$ Bu âyet Hz. Ebû Bekir ile Mistah b. Üsase arasındaki olay hakkında nazil olmuştur. Mistah, Ebû Bekir'in teyzesinin oğlu idi. Bedir'e katılmış yoksul muhacirlerden birisi idi. Ebû Bekir'in (r.a) kendisine infakta bulunduğundan başka malı olmayan yoksul biriydi. Hem de Ebubekir (r.a) akrabalığı dolayısıyla ona infak ederdi (İbn Kesir, 1991, 11/5811). Mistah, Hz. Âişe ile ilgili iftira olayına (ifk) katılıp bu hususta bazı şeyler söyleyince, Ebû Bekir (r.a) ona infakta bulunmamaya, ebediyen hiçbir şekilde ona faydalı olacak bir iş yapmamaya yemin etti. Mistah gelip özür dilediyse de Ebû Bekir yemini üzerinde israr edince bu âyet nazil oldu. Bir başka rivayete göre de müminlerden bir topluluk ifk hadisesinde söz söyleyen herkese ulaştırdıkları iyiliklerini kestiler ve “Allah'a andolsun ki Âişe hakkında ileri geri konuşan hiçbir kimseye iyiliğimiz dokunmayacaktır." dediler. Bunun üzerine bu âyet onların hepsi hakkında nazil oldu (Şahan, 2010, 299).
} 
Ayet inanan kimselerin yakınlarına karşı affedici ve hoşgörülü olmalarını emretmekte, Allah'ın bağışlayıcı ve hoşgörülü olduğunu hatırlatarak aksi bir tutum sergilememeleri konusunda uyarmaktadır. Ayet bu tür olayları tahlil ederken kullanmış olduğu ölçü ile yakın akrabalar arasında hoşgörüyü yaymıştır (Derveze, 2014, 6/359). Ayetin ihtiva ettiği hususlar davranış düzlemine aktarıldığı takdirde toplumsal düzeni sağlamada önemli bir rol oynayacaktır. Olumlu eğilimler yakın akrabalar arasında karşılıklı gelişme sağlayacak bir anahtardır.

\section{Olumlu Kontrol Bağlamında Dinin Bütünleştirici Rolü ve Sıla-i Rahim}

Sıla-i rahimin olumlu bir kontrol mekanizması oluşu dinin toplumu bütünleştirici rolünü öne çıkarmaktadır. Nitekim Durkheim'e göre “din, kutsal şeylerle ilgili inanç ve uygulamaların bir dayanışma sistemi; kutsal şeylere bağlı kişilerle oluşan ve onları tek bir ahlaki topluluk halinde birbirine bağlayan inanç ve uygulamalar bütünüdür." (Arslantürk, 2015 , 261). Din insanları sembol, değer ve normlar aracılığıyla, temelden ve en sıkı bağlarla bir arada tutan güçtür. Dini, toplumsal yapının devamı için temel esaslardan biri olarak kabul eden Durkheim'e göre, kutsallık atfedilen unsurlar dinin toplumu bütünleştirici gücünün ve toplumsal kontrolün sağlanmasının bir ifadesidir (Macionis, 2013, 489). Din toplum içerisinde sahip olduğu bütünleştirici işlevini, kendisine bağlı olan bireyler arasında gerçekleştirmiş olduğu çeşitli ilişki noktalarıyla sağlar. Aynı dini inancı paylaşmak, aynı ibadetleri gerçekleştirmek bu ilişki noktalarından bazılarıdır.

İbn Haldun'un toplum sinıflamasında tabii olarak yer alan ve şehirde hayatı ihtiva eden hadari toplum (İbn Haldun, 2017, 324), akrabalar arasında oluşan bütünleşme gücünü ortadan kaldıran çeşitli sebepleri bünyesinde barındırmaktadır. Bu durumun sebep olduğu akraba ilişkilerinin giderek ortadan kalkması durumu toplum içerisinde bir çözülmeye sebebiyet verecektir. Sosyal yapının uyum içerisinde işleyişi ve iş birliği ile sürdürülmesi, içselleştirilmiş bir hal alan manevi değer ve normların bütünleştirici ve bağlayıcı rolü ile mümkündür. Bu noktada dinin bütünleştirici rolü öne çıkarak sosyal çözülmeyi engellemektedir. Din toplumlara sunmuş olduğu değerlerle birleştirici gücünü ortaya koyar (Yılmaz, 2004, 98). Freyer "Kan hısımlığına yahut komşuluk esasına istinat eden grupların, aynı zamanda inanç ve ibadet birlikleri haline gelmesi mümkündür. Bu takdirde fertler arasında zaten mevcut olan grup bağının din vasıtasıyla daha da kuvvetleneceği, sıkılaşacağ 1 ve zindelik kazanacağ1 tahmin olunabilir, nitekim fiiliyatta da böyle olmuştur." sözleriyle dinin bütünleştirici rolüne işaret etmektedir (Freyer, 1964, 39).

Dinin ortaya koymuş olduğu değerler sistemi, toplumun bütünleşmesine katkı sağlar. Toplum belli bir inanç etrafında bir araya gelmişse, benzer tutum ve davranışların ortaya çıkmasını sağlayan bu inanç, bütünlük içinde yaşamaya temel oluşturur (Kasapoğlu, 2016, 43). Öyle ki klasik ve çağdaş din sosyolojisinde dinin bütünleştirici rolü, en önemli işlevleri arasında görülmekte, dinin bütünleştirici rolü üzerinde duran F. Fürstenberg ise bu durumu sosyolojinin ikinci temel kuramı olarak zikretmektedir (Kasapoğlu, 2016, 39).

İslam, toplumsal ilişkilerin değersizleştirilmesi problemini insanlığın tamamını teşkil edecek şekilde, toplumsal hayatı olumlu yönde motive edecek ilkeler getirerek çözümlemiştir. İyi insani ilişkiler İslam kültürünün, Kur'an'i ifadelerle desteklenen hassas ilkeleri arasında yer almaktadır. İslam bütünleştirici niteliğini bir yönüyle de sıla-i rahim ilişkilerinin ideal pratiğinin doğru anlaşılması ve uygulanması etrafında geliştirmiştir. Bu

Journal of Analytic Divinity, https://dergipark.org.tr/tr/pub/jad Volume 5/1 
bağlamda sıla-i rahim, yakın akrabaların gerçekte birbirlerinden razı olmaları idealini temel almaktadır. Aile ve akrabalar arasındaki karşılıklı bağlılığın güçlendirilmesi, sıla-i rahimin kesilmemesi durumunda olumlu söylemlerin Allah tarafından Kur'an' da bildirilmesi (Nisa 4/8), bireylerin sıla-i rahim ile ilgili sorumluluklarını yerine getirmesini teşvik edecektir. Sıla-i rahim ilişkisinin bütünleştirici ve istikrarlı bir yön olduğu Kur'an bağlamında anlaşılmaktadır. Sıla-i rahimin günümüzde somut pratiklerle desteklenip gözardı edilmediği sürece, olumlu bir süreç teşkil edeceği ve toplumun sosyal ilişkilerinin daha net olarak tanımlanmasına fırsat sağlayacağı görülmektedir.

\section{Olumsuz Bir Kontrol Mekanizması Olarak Sıla-i Rahim}

Soy ve evlilik (nesep ve sihriyet) Kur'an'da zikredilen, aynı zamanda akrabalık olgusunun en temel iki unsurudur (Furkan 25/54). Allah insanları ilk olarak iman bağıyla, sonrasında ise aile ve akrabalık bağlarıyla birbirlerine kenetlemiştir. Göndermiş olduğu peygamberlere eş ve çocuklar vererek bu yapının sağlam bir temele oturtulması sağlanmış (Rad 13/38), toplumun temel unsuru olan bu yapıyı bozacak her türlü işin, fitrata aykırı olarak aileye ve akrabalıklara zarar veren her türlü yolun bir azap vesilesi olduğu bildirilmiştir (Nisa 4/115-119). Kur'an' in akrabalık ilişkilerine verdiği önemi gösteren bir diğer ayette müşriklerin iktidarı ele almasıyla yeryüzünde bozgunculuk çıkaracakları ve akrabalık bağlarını parçalayacaklarına vurgu yapılmaktadır (Muhammed 47/22). Bu ayette akrabalık bağlarının koparılmasının haram olduğu açıkça ortaya konulmaktadır (Mevdudi, 1991,1/387). Ayet muhataplarının durumundan beklenen hali ve başlarına gelecekleri ihtar etmekte ve bu durumdan vazgeçmeye davet etmektedir (Kutub, 1980, 6/3297). Aynı zamanda sıla-i rahimin zıddı olan kat'i rahimi (İbnu'l Esir, T.y, 192) vurgulayan bu ayet akrabalık ilişkilerini kesen kimseleri Allah'ın lanetlediği kimseler olarak tanımlamaktadır. Ayette müşrikler bu şekilde bir kınanmaya tabi tutulurken, bu şekilde kınama yoluyla bile bir hitaba layık olmadıklarını göstermek için, akrabalarını perişan bir hale getirecek şekilde sadakatsizlik edenler "Allah'ın lanet ettiği, rahmet alanından kovduğu kimseler" olarak nitelendirilmektedir (Yazır, 1992, 7/145). Gerek Allah'a gerekse kullara verdikleri sözden dönen, yaptıkları anlaşmaları bozan, akraba, komşu ve diğer insanlarla ilişkilerini kesen, fakir fukarayı gözetmeyen, yeryüzünde fesat çıkarıp insanların arasını bozan kimselerin Allah'ın, meleklerin ve insanların lanetine uğrayacağı, ahirette ise cehenneme gidecekleri (Rad 13/25), benzer bir ayette de (Bakara 2/27) söz konusu kimselerin hüsrana uğrayacağ1 bildirilmektedir.

Olumsuz kontrol mekanizmalarının tehdit, cezalandırma gibi yaptırımlarla işlerlik kazanarak toplumdaki sapma eğilim ve tutumlarını önlemek için kullanıldığına daha önce değinmiştik. Cezalandırma eylemleri psikolojik açıdan bir tür şartlandırmayı bünyesinde barındırır. Bireylerde arzulanan yönde tavır ve davranışların yerleşmesi olumlu kontrollerin olduğu kadar, olumsuz kontrollerin de yerli yerinde kullanılmasıyla mümkündür (Dönmezer, 1983, 309). Allah Kur'an'da (Rad 13/38) toplumun en küçük yapısı olan ve aynı zamanda toplumsal düzenin sağlanmasında temelde yer alan aile ve akrabalık ilişkilerinin terkinin şiddetli bir azabın habercisi olduğunu bildiriyor. Azaba uğrayacağını bildirmek olumsuz kontrollerin belirgin bir ifadesidir. Tehdit ve 
cezalandırmayı temel alarak toplumsal düzenin aksamaması noktasında etkin ve anlamlı bir mekanizma olarak karşımıza çıkmaktadır.

Allah Kur'an'da inanan kimselerin, iman karşısında inkârı tercih eden akrabalarına karşı sevgi ve saygı göstermeyeceğini belirtmektedir (Tevbe 9/23). Ayette yabancı kişiler şöyle dursun, bireyin ailesinden bile inkârı benimseyen kişiler olursa ve bu inkarlarını terk etme ihtimalleri ortadan kalkarsa, onları dost edinmemeleri, onlarla birlikte hareket ederek küfre hizmet etmemeleri, bu kimselerle sıla-i rahim ilişkisi ve sıla- rahim hakkındaki ilahi emirler noktasında aralarına mesafe koymaları bildirilmektedir (Yazır, 1992, 4/299). Olumsuz kontrollerde en etkin yaptırımlardan biri de kamuoyunun tepkisidir. Bu tepki normlardan sapan kişilere karşı alay etme eylemi olabileceği gibi, tamamen toplum dışına atmaya kadar çeşitli şekillerde görülebilir (Burcu, 1992, 96). Mezkûr ayette İslam dini karşısında inkârı seçenlere, Kur'an'ın topluma yöneltmiş olduğu sorumlulukları hiçe sayanlara tepki olarak, yakın akrabalarının onlarla ilişkilerine mesafe koymaları, onları dost edinmemeleri bildirilmektedir. Bütün öğrenme imkanlarına rağmen İslam'a yönelik bir inkâr psikolojisi içine giren müşriklerin, kendilerince tartışmaya kapalı olan kabulleri Kur'an karşısında temelsiz duran konumlarını doğrulatmak için onları inkara sevk etmekteydi. Ayette geçen hususa örnek olarak Hz. İbrahim'in babasının inkârı kesinlik kazanınca babasına yönelik almış olduğu tepki (Tevbe 9/114) verilebilir. Hz. İbrahim babasının küfür ve dalalet yolunda olmasından duymuş olduğu üzüntü dolayısıyla sürekli olarak babası için dua ve istiğfar etmekteydi. Fakat babasının küfrü kesinlik kazanınca onun için dua ve istiğfar etmekten vazgeçmiştir (Yazır, 1992, 4/416). Nitekim insanların birbirleriyle yakınlık ve sıla ilişkileri kurmasını sağlayan unsurlardan biride inançlarıdır. Bu hususta Allah Hz. Nuh'un oğlunu inkarından ötürü onun ehli dışında zikretmiş (Hud 11/45-47), Hz. Nuh'un ve Hz. Lut'un eşlerinin inkarlarından dolayı kendileriyle yakınlık bağlarının kalmadığını bildirmiştir (Tahrim 66/10-11).

Kafirlerin üç kötü davranışından bahseden bir ayette, kafirlerin Allah'a verdikleri sözden dönmelerinden, Allah'ın birleştirilmesini emrettiği şeyleri ayırmalarından ve yeryüzünde fesat çıkartanlardan bahsedilmektedir (Bakara 2/27). Burada Allah'ın birleştirilmesini emrettiği şeyleri ayırmalarından kastedilen unsurların, bazı tefsirciler tarafından akraba ile ilgilenmek, (sıla-i rahim) ve karı kocanın arasını bulmak gibi özel ilişkileri ihtiva ettiği bildirilmiştir (Karaman vd., 2006, 1/94). Kafirlerin davranışları arasında zikredilen akraba ilişkilerinin önemsenmemesi ve toplumsal dayanışma biçimleri arasında yer alan aile ve akrabalık bağlarının ikinci plana atılması, sıla-i rahimin değersizleştirilmesi azap vesilesi olarak Kur'an'da bildirilmektedir. Bu bağlamda Allah' in bu denli önemli bir kurumun ifsat edilmesinin azap nedeni olarak bildirmesi, olumsuz kontrol mekanizmalarının işlemesinde öne çıkmaktadır. Aynı zamanda sıla-i rahimi terk ederek sosyal ilişkilerde güvensizlik ve belirsizliğe yol açan kişilerin Allah'ın lanetine uğrayacağ 1 da (Muhammed 47/22) bildirilmektedir. Bireyler, tehdit ve cezalandırma içeren bu ayetler karşısında, Kur'an'ın inşa ettiği toplum yapısına uygun davranışlar sergileyeceklerdir.

\section{Modernite ve Sıla-i Rahimin Değişen Yüzü}

Kültürel ve siyasal hareketler, demokratikleşme süreci, zaman ve uzamin farklı niteliklere bürünmesi, modernite ile birlikte değişimin hız kazanması gibi sebeplerden

Journal of Analytic Divinity, https://dergipark.org.tr/tr/pub/jad

Volume 5/1 
dolayı sosyal kontrolün birtakım krizler dönemine girdiği söylenebilir. Kültürel ve politik, ekonomi gibi çeşitli alanlarda yaşanan değişiklik, toplumsal sistemin önemli unsurlarından biri olan toplumsal ilişkilerde ve yönetim yapılanmalarında değişikliğe yol açmıştır (Bektaş - Bakacak, 2009, 45). Sumner 20. Yüzyılın ilk çeyreğinde sosyal kontrolü, kargaşadan ve kaostan uzak, aynı zamanda halkın katılımıyla özgün bir pratik olarak değerlendirirken, dönemin ilk çeyreğinden sonra ise oldukça yıkıcı ve tutarsızlık içeren kapitalizmi kurtarmaya yönelik bir amaç olarak nitelendirir. Sosyal kontrolü, iletişimin, anlamlı ilişkilerin, devletlerin gücünün ve kültürel heterojenliğin her yerde olduğunu savunan politik bir proje ve aynı zamanda kapitalizmin devamı için temel dinamik olarak değerlendiren Sumner, 20. Yüzyılın ikinci çeyreğinden sonra sosyal kontrolün temelde olduğu demokratik toplumların hayal edilmesinin zor olduğunu savunur (Bektaş Bakacak, 2009, 43-44).

Modern toplumların sosyal organizasyonu geleneksel toplumların aksine çok daha karmaşık bir yapıyı bünyesinde barındırmaktadır. Aile, akraba gibi unsurlar bu süreçte varlıklarını devam ettirmekle birlikte yeni fonksiyonlar üstlenmişler fakat mevcut fonksiyonlarından bazılarını kaybetmişlerdir (Günay, 1986, 54). Geleneksel toplumlarda öne çıkan geniş aile yapılanması akrabalık ilişkilerini kapsayan, kuzen, amca, dayı, hala gibi birçok kuşağın bir arada yaşadığı, güçlü bir dayanışma ve yardımlaşma ortamının hâkim olduğu, çok işlevli, ilişkilerin güçlü olduğu pre-modern toplumlarda görülen bir aile yapısıdır (Canatan - Yıldırım, 2011, 71). Modernleşmeyle birlikte geniş aile yapısı, bu dönemin baskın özellikleri altında çekirdek aile yapısına dönüşmüştür. Bu yapı geniş aile yapısının aksine anne baba, çocuklar ve az sayıda kişiden oluşmakta, tüketim ile karakterize olmuş topluma uygun oluşuyla öne çıkmaktadır (Canatan - Yıldırım, 2011, 74).

Geleneksel yapılarda toplumun sahip olduğu değerler etrafında şekillenen normlara itaat, bireyler arasında "biz" düşüncesini oluştururken, modern toplumlarda ilişkileri, sahip olunan "ben" düşüncesi ve aklın ve mantığın etrafında şekillenen toplumsal normlar oluşturmaktadır (Bayer, 2013, 105). Bu süreçte farklı bir boyuta taşınan bireyselcilik, modern toplumlarda kararların birlikte verildiği alt kurumlar olan aile ve akrabalık sistemlerinin yaşamış olduğu çözülmenin etrafında şekillenmiştir. Yeni bir ivme kazanan manevi boşluk, aile ve akrabalık kurumlarının birliğini zedelemiştir. Söz konusu kurumların yapılarında meydana gelen değişiklikler kültür birikimini aktarma fonksiyonunu devre dışı bırakarak, toplumsal ve kültürel normları içselleştirmeden yetişen bireylerin oluşmasına sebep olmuştur (Öz, 2019, 801-802). Akrabalık bağlarının zedelenmesiyle birlikte, sıla-i rahim ilişkilerinin güven temelli olarak çok fazla sorgulamaya tabi olmadan sağlanması gerekirken artık güvenin sağlanması için bireyler arasında tartışmalara ve çeşitli pazarlıklara ihtiyaç duyulmaktadır. Giddens'a göre Janet Finch günümüzdeki akrabalık ilişkilerini ele alırken bir "halletme" sürecinden bahseder. Finch, insanların yakınlarına nasıl davranması gerektiğini halletmelerinin zorunlu olduğuna, bu halletme süreci esnasında oluşan etik kurallarını da bağlanma kavramıla açıklar. Bireyler akrabalık ilişkilerini düzenlerken "yapılacak en uygun şey" in ne olduğunu tartıştıkları "müzakere edilen bağlanma süreci" nden geçmektedirler. Örnek olarak bir birey kayınbiraderine borç vereceği zaman bunu ailede veya toplumda uyması gereken bir yükümlülük olarak değil, paranın, doğru iş olarak nitelenmesini sağlayan bir bağlanma süreci geliştirdiği içindir (Giddens, 2010, 92). 
Toplumsal dönüşüm, değerleri basit bir konuma indirgemek, geniş ya da çekirdek aile olması fark etmeksizin aile ve akraba sistemlerini çözülmeye açık hale getirmektedir. Bu süreç aynı zamanda ailevi ilişkileri zayıflatmasına ek olarak dini değerlerin de devre dışı bırakılmasını kapsayan bir süreçtir. Aile kavramının geniş aileden çekirdek aileye dönüşümü sayısal azalmanın ve ilişkilerin atomize edilmesini kapsarken aynı zamanda sahip olunan dini değerlerinde modernizasyon sürecine denk gelmektedir. Nitekim derin bir değiştirme olarak ele alınabilecek bu süreç değerlerinden yoksun, sağlıksız ve istikrarsız toplum oluşumlarına neden olmuştur (Aktaş, 1992, 216). Mevcut durum, bu tür bir kişilik tipini küresel boyutta üretmeye devam etmekte, tek bir kurum etrafında toplanamayan aile ve akraba sistemlerini oluşturan bireylerin günden güne ortak değerleri farklılaşmakta, ana kurum olarak nitelediğimiz aile ve akrabalık kurumları büyük bir tehlike altına girmektedir. Yapılan bir araştırma, varlığını sürdüren dini inançlar ve pratiklere rağmen toplum içerisinde önemlilik arzeden evlenme, cenaze, sünnet gibi uygulamaların son otuz yıl içerisinde değer kaybına uğrayarak zayıfladığını göstermiştir (Öz, 2019, 810).

Kur'an' da fasık kimseler "Allah'ın emretmiş olduğu akrabalık ilişkilerini koparanlar ve yeryüzünde fesat çıkaran kimseler" olarak tanımlanırlar ( $\operatorname{Rad} 13 / 21-25)$. Modern kabuller, geleneksel toplumdaki geniş aile yapısından uzakta, akrabalık sistemini oluşturan bireylerin duygusal yakınlıklarının nispeten daha az olduğu bir yapıyı ihtiva eder. Bu durum Kur'an'da zikredilen "akrabalık ilişkilerini koparanlar" ifadesiyle uyuşmaktadır. İslam net bir şekilde sılanın önemine vurgu yapan çağrışımlarla, getirmiş olduğu ahlaki ilkelerle toplumu bir bütün olarak karakterize etme amacına sahiptir. Mevcut durum aralarında akrabalık ilişkisi bulunan kimselerin bir tür hissizliğe kapılmalarına kapı aralar.

\section{Sonuç}

İnsanlar ve toplumlar hangi düzlemde olursa olsun toplumsallaşma sürecinde kavramlarda, kurumlarda ve rollerde gözlenen belirsizlikleri, hayat şartları ve sorumluluklarını göz önünde bulunduran bir esneklik dahilinde, sosyal kontrol mekanizmaları aracılığıyla çeşitli düzenlemelere tabi tutmuşlardır. Toplumsal sistemin korunması ve sapma davranışlarının önüne geçmek için, değer ve ilkelerin merkezde olduğu informal kontrolün yanında yasalar ve yaptırımları da kapsayan kontrol mekanizmaları, toplum içerisinde çeşitli kaos anlarında uygulanma alanı buldukça, düzenin temelindeki yerini daha da sağlamlaştırmıştır. İnsanlık tarihi boyunca bireylerin olası eylem ve tutumlarının doğru tahminler eşliğinde istikrarlı bir temele oturtulmadığı durumlarda, toplum içerisinde yıkıcı ve kronik sorunlar baş göstermiş, devamında ise sosyal yapının çözülmesi kaçınılmaz bir hâl almıştır. Doğru temele yerleştirilmediği durumlarda mikro yapıların dahi bir sorunlar demeti oluşturacağı göz önünde bulundurulursa, sosyal kontrol mekanizmalarının toplumsal düzeni sağlamadaki geniş çaplı payı daha da belirginleşir.

Kur'an, toplumsal yapının temel dinamiklerinden olan sapma davranışlarının kontrol altına alınması niteliğini destekleyici ve güçlendirici emirleriyle, "emr-i bi'l-ma' ruf ve nehy-i ani'l münker" ilkesi etrafında bir toplum yapısı oluşturmuştur. Birçok alanda köktenci toplumsal düzenlemelerle kalıcı, istikrarlı, dinamik bir toplum yapısı, aynı zamanda saf ve evrensel bir yaşantı ortaya koymuştur. Kur'an toplumu dönüştürürken, ideal İslami pratiğin sınırları dışında yer alan insan ilişkilerine, özelde ise aile ve akrabalık

Journal of Analytic Divinity, https://dergipark.org.tr/tr/pub/jad Volume 5/1 
ilişkilerine büyük bir önem atfetmiş, sıla-i rahimin üzerinde hassasiyetle durmuş, bu yaklaşımıyla ilişki dengelerini toplumsal yapının devamını sağlayacak şekilde yeniden düzene koymuştur.

Sosyal kontrol mekanizmaları olumlu kontrol ve olumsuz kontrol başlıkları altında işlerlik kazanır. Her iki mekanizmada düzeni bozma potansiyeline sahip davranışların ve hasmane tutumların terkedildiği, ahlaki temellere dayalı bir toplum dokusu oluşturmayı hedefler. Kur' an'i bağlamda olumlu kontroller, sıla-i rahim ilişkilerinin Kur'an'da bildirilen şekilde uygulanması noktasında ödül üzerine güdülenme oluşturarak işlerlik kazanır. Aile ve akraba ilişkilerinin karşılıklı dayanışmayla doyurucu noktalara ulaşması akabinde hayatın olumlu sonu olan cennetlerin sunulacağının bildirilmesi olumlu kontrollerin bir yansımasıdır. Sıla-i rahim ilişkilerinin statik bir çerçeveden uzakta dinamik bir temele oturtulması, akrabalar arasındaki olumsuz duyguların ortadan kalkmasını sağlayacak olumlu kontroller etrafında şekillenen aile yapısıyla mümkündür. Olumlu kontrollerin dikkate alınmadığı durumlarda ise dar bir alana sıkışmış çıkarcı amaçların toplumdan soyutlanmaya sebebiyet vereceği ve hasmane tutumların ilişkileri oldukça sınırlayıcı bir konuma sürükleyeceği aşikardır. Bu tutumlar Kur'an'ın toplumu geliştirici yapısında uzakta, tutarlılık ve yapıcılık içermeyen, zedeleyici durumlardır. Kur'an söz konusu tutumların sebebiyet vereceği değerlerin ve sıla-i rahim olgusunun küçümsenmesi ve köreltilmesi durumunu önlemek için, toplumsal düzenin sorunsuz bir şekilde sürdürülmesine yönelik çeşitli yaptırımlara yer vermiştir.

Söz konusu yaptırımlar olumsuz kontrol başlığı altında kendisine yer bulmaktadır. Olumsuz kontroller cezalandırma ve tehdit üzerinde şekillenir. Aynı zamanda bu kontroller Kur'an'ın 1srarlı sıla-i rahim vurgusunun bir yansımasıdır. Sinırları bu kadar hassas bir kurumun sapma eğilimlerine maruz kalmaması toplumsal hayatın kontrol altına alınmasında noktasında önem arz etmektedir. Nitekim sıla-i rahim ilişkilerinin ikinci plana atılarak değersizleştirildiği durumlarda toplumsal dayanışma biçimi olarak aile kurumu çözülme yaşayacaktır. Aile ve akrabalık ilişkilerini önemsemeyerek zayıflatan kimselerin ise Allah'ın azabına ve lanetine uğrayacağı bildirilir.

Kur'an'ın evrensel oluşu itibariyle bu ssrarlı sıla-i rahim tavrı, en çokta aile ilişkilerinin zayıfladığı modern toplumlara hitap etmektedir. Modernite ile birlikte aile ve akrabalık ilişkileri farklı bir görünüm arz ederek geleneksel toplumların aksine atomize edilmiş bir yapıya bürünmüştür. Bu durum toplumsal hayatın çeşitli alanlarında da domino etkisi ortaya çıkarmış, katı kişiliklerin yetiştiği, kültürün aktarılma fonksiyonunun zedelendiği bir süreci tetiklemiştir. Bireyleri karşılıklı olarak ve güçlü ilişkilerle bütünleyen sıla-i rahim ilişkilerinin zayıflaması, bulanıklaşması ve manevi değerlerin tükeniş sürecine girmesi, birbirlerinden yalıtılmış bireylerden oluşan bir toplum yapısını meydana getirir. Nitekim modern toplumda yer alan çekirdek aile ve sıla-i rahim ilişkileri, öz benliğine yabancılaşan bir hüviyet etrafında şekillenmektedir. 


\section{Kaynakça}

Akçakaya, Nuh. "Sosyal Kontrolün Başka Fenomenlerï Gramatik Yapılar". Akademik Incelemeler Dergisi 14/1 (30 Nisan 2019), 403-442.

Aktaş, Cihan. Modernizmin Evsizliği ve Ailenin Gerekliliği. İstanbul: Beyan Yayınları, 1992.

Altuntop, Serkan. "Suça Bakışta Kontrol Yaklaşımı ve Kontrol Teorileri". Kriminoloji Dergisi, 1-15.

Arslantürk, Zeki. Kutsal'ın Tecrübesi Din Sosyolojisine Giriş. İstanbul: Çamlıca Yayınları, 2015.

Bauman, Zygmunt. Postmodernlik ve Hoşnutsuzlukları. çev. İsmail Türkmen. İstanbul: Ayrintı Yayınları, 2000.

Bauman, Zygmunt. Yasa Koyucular ile Yorumcular. çev. Kemal Atakay. İstanbul: Metis Yayınları, 1996.

Bayer, Ali. "Değişen Toplumsal Yapıda Aile". Şırnak Üniversitesi İlahiyat Fakültesi Dergisi 4/8 (01 Aralık 2013), 101-129.

Bektaş, Rahşan Balamir- Bakacak, Ayça GELGEÇ. "Modernitenin Sosyal Kontrol Söyleminin Değişen Görünümleri". Hacettepe Üniversitesi Edebiyat Fakültesi Dergisi 26/1 (15 Haziran 2009), 33-48.

Berger, Peter Ludwig. "Dini Kurumlar" Toplumbilimi Yazıları. çev. Adil Çiftçi. İzmir: Anadolu Yayınları, 1999.

Burcu, Esra. Sosyal Değişme Süreci İçerisinde Farklı Sosyo-Ekonomik ve Kültürel Yapıya Sahip Aileler Arasında Sosyal Kontrolün Etkinliği ve Bazı Sapmış Davranışların Nedenlerine İlişkin Sosyolojik Değerlendirmeler. Ankara: Hacettepe Üniversitesi Sosyal Bilimler Enstitüsü, Yüksek Lisans Tezi, 1992.

Burke, Roger Hopkins. An Introduction to Criminological Theory. Willan Publishing, Third Edition., 2009.

Canatan, Kadir- Yıldırım, Ergün. Aile Sosyolojisi. İstanbul: Aç1lım Kitap Yayınları, 2011.

Demir, Sevim Atila. “Modern Toplumdaki Kontrol Mekanizmaları: Foucault ve Disiplin Kuşatması". Kahramanmaraş Sütçü İmam Üniversitesi Sosyal Bilimler Dergisi 6/2 (01 Haziran 2009), 1-12.

Demirci, Muhsin. Kur'an'da Toplumsal Düzen. İstanbul: M. Ü. İlahiyat Fakültesi Vakfı Yayınları, 2013.

Derveze, İzzet. Et- Tefsirul Hadis. çev. Muharrem Önder- Vahdettin İnce. İstanbul: Düşün Yayıncilık, 2014.

Dönmezer, Sulhi. "Türk Toplumunda Sosyal Kontrol Arac1 Olarak Ceza ve Ödüllendirme". İstanbul Üniversitesi Hukuk Fakültesi Mecmuası 48/1-4 (1983), 295315.

Eren, Mehmet. "Kur'an ve Sünnete Göre Sıla-i Rahimin Önemi". İslam Hukuku Araştırmalarn Dergisi 12 (2008), 369-380.

Journal of Analytic Divinity, https://dergipark.org.tr/tr/pub/jad Volume 5/1 
Fichter, Joseph H. Sosyoloji Nedir? çev. Nilgün Çelebi. Konya: Anı Yayıncılık, 3. Basım, 2016.

Filinte, Handan. Mekki Surelerde Kişilik İnşası. İstanbul: İstanbul Sabahattin Zaim Üniversitesi Sosyal Bilimler Enstitüsü, Yüksek Lisans Tezi, 2018.

Freyer, Hans. Din Sosyolojisi. çev. Turgut Kalpsüz. Ankara: Ankara Üniversitesi Basımevi, 1964.

Giddens, Anthony. Mahremiyetin Dönüşümü. çev. İdris Şahin. İstanbul: Ayrıntı Yayınlar1, 2010.

Giddens, Anthony. Sociology. Cambridge: Polity Press, 2006.

Güler, İlhami. Allah'ın Ahlakiliği Sorunu. Ankara: Ankara Okulu Yayınları, 1998.

Günay, Ünver. “Modern Sanayi Toplumlarında Din”. Erciyes Üniversitesi İlahiyat Fakültesi Dergisi 3 (1986), 41-88.

Güngör, Özcan. “Kur'an’ da Sosyal Bütünleşme”. Diyanet İlmi Dergi 40/3 (2004), 31-48.

İbn Haldun. Mukaddime. çev. Süleyman Uludağ. İstanbul: Dergâh Yayınları, 2017.

İbn Kesir. Hadislerle Kur'an'ı Kerim Tefsiri. çev. Bekir Karlığa- Bedrettin Çetiner. İstanbul: Çağrı Yayınları, 1991.

İbnu'l Esir. Nihaye fi garibil hadis ve'l eser. Kahire: Mektebetü'l İslamiyye, T.y.

İçli, Tülin Günşen- Burcu, Esra. “İnformal Sosyal Kontrolün Sağlanmasında Ailelerin Gelir ve Eğitim Düzeyinin Önemi: Ankara' da Uygulamalı Bir Çalışma". Hacettepe Üniversitesi Edebiyat Fakültesi Dergisi 10/1 (15 Haziran 1993), 43-56.

Karaman, Hayrettin vd. Kur'an Yolu Türkçe Meal ve Tefsir. Ankara: Diyanet İşleri Başkanlığı Yayınları, 2006.

Kasapoğlu, Abdurrahman. "Kur'an'a Göre Dinin Toplumsal Bütünleşmedeki Rolü". Hikmet Yurdu Düşünce-Yorum Sosyal Bilimler Araştırma Dergisi 9/ (01 Ocak 2016), 22-116.

Kutub, Seyyid b. Kutub b. İbrahim Seyyid. Fi zılali'l-Kur'an. Beyrut: Darü'ş-Şüruk, 1980.

Macionis, John J. Sosyoloji. çev. Vildan Akan. Ankara: Nobel Yayınları, 2013.

Mevdudi, Ebu'l A'la. Tefhimu'l Kur'an. çev. Muhammed Han Kayani vd. İstanbul: İnsan Yayınları, 1991.

Nakvi, N. Haydar. Ekonomi ve Ahlak. çev. İlhan Kutluer. İstanbul: İnsan Yayınları, 1985.

Nar, Mehmet Şükrü. "Kültürel Hukuk: Geleneksel Kontrol Mekanizmaları”. Türkiye Barolar Birliği Dergisi 26/108 (2013), 273-290.

Oktik, Nurgün. "Sosyal Kontrol, Çocuk ve İnternet". Bildiriler Kitabı 1. Türkiye Çocuk ve Medya Kongresi. 1/298-309. İstanbul: Çocuk Vakfı Yayınları, 2013.

Okumuş, Ejder. "Din ve Sosyalleşme". Turkish Studies- International Periodical For The Languages, Literature and History of Turkish or Turkic 9/11 (2014), 429-454. 
Öz, Nedim. "Modern-Seküler Süreçte Ailenin Çözülmesi”. Kilis 7 Aralık Üniversitesi İlahiyat Fakültesi Dergisi 6/11 (30 Aralık 2019), 795-835.

Sicistani, Ebu Davud Süleyman b. Eş' as es-. Sünen-i Ebu Davud. çev. Necati YenielHüseyin Kayapınar. İstanbul: Şamil Yayınevi, 1989.

Şahan, Ramazan. Kur'ân-I Kerîm'de Akrabalı. İstanbul: Marmara Üniversitesï Sosyal Bilimler Enstitüsü, Doktora Tezi, 2010.

Şahin, Nur. 19. Yüzyıl Ütopyalarında Sosyal Kontrol Mekanizmaları. Bolu: Bolu Abant İzzet Baysal Üniversitesï Sosyal Bilimler Enstitüsü, Yüksek Lisans Tezi, 2019.

Şentürk, Mustafa. “Kur'an'da Toplumsal Değişme Olgusu -Disiplinlerarası Bir Giriş Denemesi". Marife Dini Araştırmalar Dergisi 14/2 (01 Ekim 2014), 25-42.

Şentürk, Recep. “Değişen Toplum ve Ahlak: Modern Türk Toplumunda Değerler Krizi”. Çă̆ımızın Ahlak Bunalımı ve Çözüm Arayışları. 71-82. Ensar Neşriyat Yayınları, 2009.

Tekin, Mustafa. "Bir Sosyal Kontrol Aracı Olarak Ahilik ve Toplumsal Dinamikleri". Necmettin Erbakan Üniversitesi İlahiyat Fakültesi Dergisi 21/2 (01 Ekim 2006), 219235.

Vural, Engin. Ütopya ve Distopyalarda Sosyal Kontrol. Ankara: Hacettepe Üniversitesi Sosyal Bilimler Enstitüsü, Yüksek Lisans Tezi, 2011.

Watt, W. Montgomery. Kur'an'a Giriş. çev. Süleyman Kalkan. Ankara: Ankara Okulu Yayinları, 2000.

Yazıcı, Mehmet. "Değerler ve Toplumsal Yapıda Sosyal Değerlerin Yeri”. Fırat Üniversitesi Sosyal Bilimler Dergisi 24/1 (31 Ocak 2014), 209-223.

Yazır, Elmalılı M. Hamdi. Hak Dini Kur'an Dili. İstanbul: Zehraveyn Yayınları, 1992.

Y1lmaz, Bilal. İbn Haldun'a Göre Din-Toplum İlişkisi. Bursa: Uludağ Üniversitesi/Sosyal Bilimler Enstitüsü/Felsefe ve Din Bilimleri Anabilim Dalı, Yüksek Lisans Tezi, 2004.

Yılmaz, Ömer. Geçmişten Günümüze Tasavvuf ve Tarikatlar. Ankara: Akçağ Yayınları, 2019.

Journal of Analytic Divinity, https://dergipark.org.tr/tr/pub/jad

Volume 5/1 